Robert Milivojević, mag. oec. ${ }^{1}$ Doc. dr. sc. Vanja Krajinoviće

\title{
ULOGA DIONIKA TURISTIČKE DESTINACIJE U PREVLADAVANJU UČINAKA PREKOMJERNOG TURIZMA
}

\section{ROLE OF STAKEHOLDERS IN OVERCOMING IMPACTS OF OVERTOURISM IN A DESTINATION}

SAŽETAK: Dosadašnji razvoj turizma bio je najvećim dijelom orijentiran na rast turističkog prometa, pri čemu su pitanja održivosti razvoja i njegovog utjecaja na lokalnu zajednicu uglavnom bila zanemarivana ili marginalizirana. Međutim, suvremeni razvoj društva omogućava sve većem broju ljudi uključivanje u turistička kretanja pa se i pritisak na destinacije, posebice na one koje su najposjećenije na međunarodnoj razini, povećava. Stoga se u posljednje vrijeme naglašava problem prekomjernog turizma i njegovih posljedica na kvalitetu života lokalnog stanovništva u destinacijama u kojima se pojavljuje. Fenomen prekomjernog turizma reakcija je lokalnog stanovništva na preveliko opterećenje njihovog okruženja i nemogućnost ostvarenja optimalnih životnih uvjeta. Brojne se destinacije suočavaju s posljedicama prekomjernog turizma, a dionici tih destinacija na svim razinama uključuju se u rješavanje nastalih problema. Cilj ovog rada je analizirati čimbenike koji su uvjetovali pojavu i razvoj prekomjernog turizma te utvrditi mogućnosti prevladavanja učinaka prekomjernog turizma na razini destinacija. Doprinos rada očituje se u njegovoj primjenjivosti u analizi uzroka pojave prekomjernog turizma, kao i u definiranju uloge pojedinih dionika destinacije u prevladavanju problema uzrokovanih ovakvim razvojem turizma.

KLJUČNE RIJEČI: prekomjerni turizam, dionici turizma, održivi razvoj turizma, turistička destinacija

ABSTRACT: Former tourism development was dominantly oriented towards the growth of tourist arrivals and turnover, thereby ignoring and marginalizing the issue of sustainability and impacts of such development on the local community. However, development of contemporary society enables the ever-growing number of people to become a part of tourism, which increases the pressure on the area, especially in most visited world

Robert Milivojević, mag. oec., Zagrebačka banka, e-mail: robertm7090@gmail.com

Dr. sc. Vanja Krajinović, docentica, Ekonomski fakultet Zagreb, Katedra za turizam, Trg J. F. Kennedyja 6,e-mail: vkrajinovic@efzg.hr 
destinations. Therefore, the problems arising from overtourism have become more emphasized recently, together with its consequences on the quality of life of the local community in destinations within which it occurs. The phenomenon of overtourism is a reaction of local community on the overpressure of their surrounding and inability to achieve optimal living conditions. Numerous destinations are dealing with consequences of overtourism, while their stakeholders on all levels are taking part in solving the incurred problems. The objective of this paper is to analyze factors which have initiated this phenomenon and development of overtourism, as well as to determine possibilities of overcoming the effects of overtourism on destination level. The contribution of the paper is reflected in its applicability in determining causes of overtourism, but also in defining the role of different stakeholders in overcoming the problems caused with such tourism development at destination level.

KEY WORDS: overtourism, tourism stakeholders, sustainable tourism development, tourism destination

\section{UVOD}

Izazovi suvremenog turizma jasno se očituju u fenomenu prekomjernog turizma. Usprkos svim spoznajama o nužnosti i specifičnostima upravljanja razvojem turizma, brojne su destinacije suočene s prekomjernim turizmom te su naišle na nepremostive poteškoće s kojima se manje ili više uspješno nose. U kontekstu prekomjernog turizma upravo je razina svijesti dionika o ozbiljnosti nastalih problema u destinaciji ključan element uspješnosti rješavanja izazova upravljanja. Destinacije poput Amsterdama, Barcelone, Berlina, Dubrovnika, Praga ili Venecije na različite se načine suočavaju s problemima nastalim pojavom i razvojem prekomjernog turizma, a njihova buduća opstojnost na tržištu ovisi upravo o načinima rješavanja izazova povezanih s ovom pojavom.

Iako se naziv prekomjerni turizam javio relativno nedavno, o njemu se u drugim kontekstima raspravljalo i puno ranije, posebice u okviru odnosa domaćina i gostiju na razini turističke destinacije. Stoga je moguće zaključiti da su se njegove implikacije mogle predvidjeti puno ranije. Razlog za to je činjenica da pojam predstavlja nadogradnju pojma indeksa iritacije između lokalnog stanovništva i turista (Doxey, 1975), teorije prihvatnog kapaciteta u turizmu (O’Reilly, 1986), kao i koncepta životnog ciklusa turističke destinacije (Butler, 1980). Štoviše, upravo su ovi pojmovi polazište brojnih istraživanja prekomjernog turizma.

Prekomjerni turizam moguće je definirati kao „učinak turizma na destinaciju ili na njene dijelove, koji prekomjerno utječe na percipiranu kvalitetu života građana i/ili na kvalitetu iskustva posjetitelja na negativan način“ (UNWTO, 2018:6). Do povećane razine svjesnosti o važnosti ovog problema dovela je povećana medijska pažnja koja mu je dana, što je rezultiralo i povećanom pažnjom znanstvene zajednice. Prema podacima Google Scholar-a (2019a), u razdoblju od 2010. do 2016. godine naziv prekomjerni turizam javlja se kao ključna riječ u otprilike 1.500 znanstvenih i stručnih radova. Međutim, nakon toga broj radova se značajno povećao te je u razdoblju od 2010. do 2019. godine objavljeno otprilike 3.700 znanstvenih i stručnih radova s ključnom riječi prekomjerni turizam (Google Scholar, 2019b). Znanstvena istraživanja promatraju ovaj problem iz perspektive njegovog utjecaja na kvalitetu života lokalnog stanovništva, utjecaja na zadovoljstvo turista, kvalitetu okoliša, specifičnosti upravljanja i brojne druge elemente, ali upravo je pojava problema, a ponegdje 
i njegova eskalacija, dovela do otpora lokalnog stanovništva prema daljnjem razvoju turizma u pojedinim destinacijama (Barcelona, Venecija ili Hallstatt, primjerice).

Stoga su ciljevi ovog rada sljedeći:

1) Definirati čimbenike pojave prekomjernog turizma i analizirati one ključne, koji se javljaju u većini destinacija.

2) Izdvojiti potencijalne strategije prevladavanja prekomjernog turizma u destinacijama i definirati one skupine dionika koje su ključne za prevladavanje tih problema.

$\mathrm{S}$ obzirom na to da se radi o relativno novom području istraživanja, ovaj se pregledni rad oslanja na sekundarne izvore podataka. Doprinos rada očituje se u identifikaciji ključnih problema uzrokovanih pojavom prekomjernog turizma u destinacijama, kao i u definiranju uloge pojedinih skupina dionika u prevladavanju problema koji se javljaju na razini turističke destinacije.

\section{POJAM I ZNAČAJ PREKOMJERNOG TURIZMA}

Suvremeni razvoj turizma posljednjih je godina pod velikim pritiskom povećanog broja turističkih dolazaka na međunarodnoj razini općenito, a posebice na razini turističkih destinacija. Zbog dugotrajne usmjerenosti na rast fizičkih pokazatelja, a ne na ukupni razvoj, brojne su destinacije podlegle problemu prekomjernog turizma koji se može smatrati izravnom posljedicom strategija usmjerenih isključivo na rast (Capocchi et al., 2019; Dodds i Butler, 2019; Oklevik et al., 2019; Wall, 2020). Neoliberalni pristup u svakom je slučaju omogućio upravo ovakav razvoj, a istovremeno nije u postupnosti pripremio dionike destinacija na njegove posljedice. Stoga je medijska pažnja koja se pridaje pojavi nazvanoj prekomjerni turizam ključna u pronalaženju brzih i optimalnih rješenja za njegove posljedice na razini destinacija (Eckert et al., 2019).

Prekomjerni turizam još uvijek nema svoju jedinstvenu, općeprihvaćenu definiciju, što ga jednim dijelom otvara za brojne mogućnosti daljnjih istraživanja, ali ga istovremeno ne ograničava na istraživanja iz samo jednog aspekta. Ovaj pojam nadilazi problematiku zasićenja turističkih destinacija, a jedna od definicija koje tomu ide u prilog navodi da je prekomjerni turizam ,,situacija u kojoj utjecaj turizma, u određenom trenutku i na određenom mjestu, prelazi granice fizičkog, ekološkog, društvenog, ekonomskog, psihološkog i/ili političkog kapaciteta“ (Peeters et al., 2018:19). Goodwin, pak, definira prekomjerni turizam kao situaciju u kojoj „,destinacije u kojima domaćini ili gosti, lokalno stanovništvo ili posjetitelji, osjećaju da je broj posjetitelja prevelik i da su kvaliteta života na tom području ili kvaliteta iskustva posjetitelja neprihvatljivo smanjene“ (2017:1). Prekomjerni turizam zapravo predstavlja previše posjetitelja na određenom lokalitetu odnosno u određenoj destinaciji. Problem kod ovog pristupa definiranju koncepta jest činjenica da je „previše“ subjektivna kategorija, a unutar destinacija definiraju ju lokalno stanovništvo, domaćini, vlasnici poduzeća u turizmu i turisti (Responsible Travel).

Moguće je tvrditi da se pojam prekomjernog turizma dijelom nastavlja na koncept kapaciteta nosivosti, no on uključuje dodatnu razinu svijesti, onu o utjecaju turizma na kvalitetu života lokalnog stanovništva. Upravo je taj aspekt turizma najvažniji prema teoriji održivog razvoja turizma. Kvalitetno osmišljene strategije razvoja pretpostavljaju uvažava- 
nje koncepta održivosti i kao takve djeluju na povećanje kvalitete života lokalnog stanovništva. Prekomjerni turizam je u svojoj osnovi kvalitativni koncept koji naglasak stavlja na iskustvo lokalnog stanovništva i posjetitelja destinacija, a ta su iskustva ovisna o različitim socio-ekonomskim promjenama koje utječu na trenutni masovni rast turizma, posebice u urbanim sredinama (Nilsson, 2020). Naime, urbanizacija, standardizacija i globalizacija značajno utječu na način života u suvremenom okruženju, a velikim su dijelom inicijatori masovnog turizma, odnosno posljedično imaju značajan utjecaj na održivi razvoj turizma. U tom je kontekstu održivi razvoj turizma moguće definirati kao turizam koji uzima u obzir sadašnje i buduće ekonomske, društvene i ekološke učinke, uzimajući u obzir potrebe posjetitelja, sustava turizma, okoliša i lokalnih zajednica (UNWTOa).

U destinacijama u kojima razvoj nije temeljen na održivim strategijama često dolazi do otpora lokalnog stanovništva prema budućem razvoju. Prekomjerni je turizam u tom smislu točka krajnjeg nezadovoljstva dosadašnjim razvojem turizma. Međutim, istraživanje Papathanassisa (2017) usmjereno je upravo na problematiku povezanosti prekomjernog turizma i medijskog senzacionalizma, gdje se u središte problema stavlja razina uključenosti destinacijskog menadžmenta, a ne nužno pokazatelji pritiska turističkih dolazaka i noćenja na lokalno stanovništvo i lokalnu infrastrukturu.

Problematika prevladavanja prekomjernog turizma proizlazi iz činjenice da „održivost tek trebamo doseći, ali sustav još uvijek ne razumije u potpunosti na koji način“ (Seraphin, Sheeran i Pilato, 2018:374). Štoviše, središnji problem istraživanja u raspravama o prekomjernom turizmu ravnotežni je odnos između prava turista i prava lokalnog stanovništva da žive ondje gdje žele (Perkumienè i Pranskūnienè, 2019:2). Upravo iz tog razloga prekomjerni turizam često rezultira prosvjedima lokalne zajednice koji su usmjereni protiv daljnjeg razvoja turizma. Ovaj pojam nije moguće jednoznačno odrediti, on je usko povezan s problematikom održivosti, mjerenjem učinaka turizma na prostor i društvenu zajednicu u ekonomskom i društvenom kontekstu, ali i povećanom razinom korištenja novih tehnologija (Capocchi et al., 2019:15). Dionici destinacija navode da je prekomjerni turizam zapravo nagomilavanje različitih učinaka i percepcija koje se odnose na ponašanje turista, ali i na poteze i odnose s dionicima, kao i na promjene u društvenom, ekonomskom i fizičkom okruženju (Koens, Postma i Papp, 2018:5). Moguće je, stoga, zaključiti da su središnji problem prekomjernog turizma upravo odnosi različitih skupina dionika, uz naglašavanje važnosti posvećenosti posebnih napora kvaliteti života lokalne zajednice. Istraživanje koje su proveli Jover i Díaz-Parra (2020:3) pokazalo je da je društveni konflikt u gradovima na Mediteranu eskalirao s porastom broja turističkih dolazaka koji su premašili kapacitete nosivosti destinacija.

Zaključno je moguće tvrditi da prekomjerni turizam u svojoj osnovi predstavlja eskalaciju ranije definiranih izazova razvoja turizma. Konkretno se to odnosi na prihvatni kapacitet, zasićenost destinacija, održivi razvoj turizma, a u novije vrijeme na turizmofobiju, gentrifikaciju i sl. Prema Nambergeru et al. (2019:455), prekomjerni turizam odnosi se na prekoračenje mogućnosti turizma, na što se može odgovoriti zahtjevom za postavljanjem granica rasta ili zaustavljanjem rasta. Ovaj je pojam izrazito dinamičan i višedimenzionalan kada je riječ o znanstvenim istraživanjima. Moguće ga je promatrati u kontekstu političke ekonomije, geografije, antropologije, urbanog, ruralnog i priobalnog planiranja, marketinga, destinacijskog menadžmenta i drugih aspekata (Milano, Novelli i Cheer, 2019a:1859). Milivojević navodi da je „kao glavne karakteristike prekomjernog turizma moguće izdvojiti 
preveliki broj turista te njihove štetne učinke, koji se najčešće povećavaju zahvaljujući izraženoj sezonalnosti, što u konačnici dovodi do snažnog nezadovoljstva lokalnog stanovništva“ (2019:8). Sve navedeno dovodi do zaključka da je prekomjerni turizam središnji problem znanstvenih istraživanja u području suvremenog razvoja turizma, a definiranje uloge pojedinih skupina dionika od ključne je važnosti za prevladavanje problema uzrokovanih prekomjernim turizmom, što u konačnici pretpostavlja kreiranje održivog okruženja na razini destinacije.

\section{IZAZOVI UPRAVLJANJA TURISTIČKIM DESTINACIJAMA POD UTJECAJEM PREKOMJERNOG TURIZMA}

U suvremenom okruženju sve je veći izazov kako upravljati destinacijom na održiv način. Štoviše, ,neke popularne turističke destinacije koje je zadesio prekomjerni turizam odgovaraju kombinacijom poreza, zakona i regulativa, bez sumnje promovirane praznim hodom lokalnih zajednica i povezanih društvenih pokreta“ (Milano, Novelli i Cheer, 2019b:355). Upravo je iz tih razloga, prema mišljenju autora, ključni faktor uspjeha definiranje čimbenika koji su doveli do pojave prekomjernog turizma u destinacijama, a sve s ciljem omogućavanja kreiranja politika i strategija budućeg razvoja turizma koje će omogućiti optimalne životne uvjete lokalnoj zajednici, ali i kvalitetna iskustva njihovim posjetiteljima.

\subsection{Odabrani faktori koji su inicirali pojavu prekomjernog turizma}

Brojni su faktori doveli do pojave prekomjernog turizma u destinacijama. Dodds i Butler (2019:6) navode sljedeće čimbenike: rastući broj turističkih dolazaka, cjenovnu prihvatljivost putovanja, nove skupine turista, stanje svijesti u kojem je naglasak na rastu, usredotočenost na kratki rok, nadmetanje za prostor i usluge, veći pristup medijima i informacijama, gubitak kontrole nad turističkim dolascima, neravnomjernu raspodjelu moći među dionicima destinacija, fragmentiranost i suprotstavljenost interesa dionika. Nadalje, kao najvažnije faktore koji su uzrokovali pojavu prekomjernog turizma Milivojević (2019:15) navodi „snižavanje troškova putovanja, pojavu ekonomije dijeljenja, društvene i političke trendove te Internet i društvene medije“. Panayiotopoulos i Pisano (2019:394), pak, kao uzroke problema navode jeftine letove, razvoj industrije krstarenja i ekonomiju dijeljenja, što dovodi do povećanog broja turista na ulicama gradova. Velikim dijelom dolazi do preklapanja prepoznatih trendova kod većine autora, a ishodište problema zasigurno se može naći u neoliberalnom okviru razvoja turizma. Higgins-Desbiolles et al. (2019) tvrde da je pojava prekomjernog turizma izravna posljedica usmjerenosti na rast, što je desetljećima bilo središte razvojnih strategija. Posljedično, lokalne zajednice preuzele su proaktivnu ulogu u procesu smanjenja broja turista koji posjećuju destinacije (Koens, Postma i Papp, 2018; Namberger et al., 2019; Smith, Pinke Sziva i Olt, 2019).

Avond et al. (2019:556) navode da se uzorci prekomjernog turizma mogu izdvojiti kako na strani ponude, tako i na strani potražnje. Tako na strani ponude navode nedostatak resursa, loš menadžment, ranjivost receptivnih područja, neadekvatno planiranje razvoja 
turizma, nedostatak stručnosti u upravljanju te nedovoljno poznavanje važnosti održivog razvoja turizma. Na strani potražnje, pak, navode veću spremnost na potrošnju financijskih sredstava, bolje ekonomske uvjete, tehnologiju putovanja, globalizaciju, sofisticiranost potražnje, promjene u stilu života i emancipaciju žena. Svi ovi faktori čine skupinu socio-ekonomskih poticaja razvoja prekomjernog turizma i kao takvi značajno doprinose masovnosti turizma, što je svakako moguće izdvojiti kao jedan od ključnih inicijatora ove pojave.

Od svih prethodno navedenih faktora kao najvažnije uzroke pojave prekomjernog turizma autori izdvajaju povećan broj međunarodnih turističkih dolazaka i pojavu ekonomije dijeljenja. Broj međunarodnih turističkih dolazaka 2018. godine iznosio je 1,4 milijarde, što čini povećanje od $5 \%$ u odnosu na prethodnu godinu (UNWTO, 2019a:2), uz naglašavanje tendencije rasta. Ovaj podatak pretpostavlja izniman pritisak na najposjećenije svjetske destinacije. Međutim, za potpunu analizu veličine turističkog prometa i njegovog utjecaja na pojavu prekomjernog turizma na globalnoj razini, a posebice na razini destinacija, na Grafu 1 dan je pregled međunarodnih turističkih dolazaka u razdoblju od 1950. do 2019. godine.

Graf 1: Pregled kretanja broja međunarodnih turističkih dolazaka u razdoblju od 1950. do 2019. godine (u milijunima)

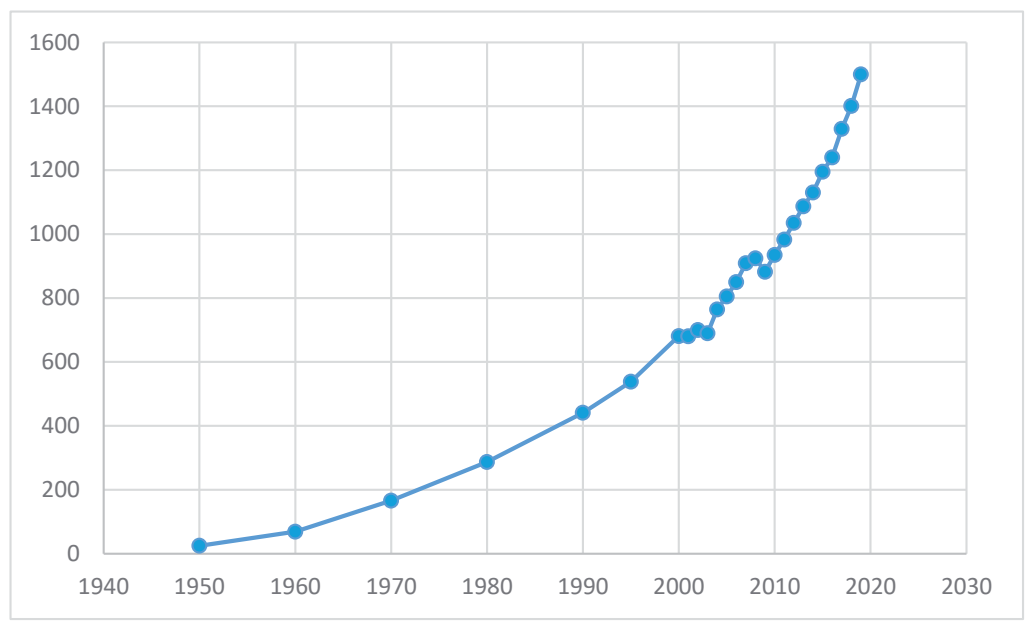

Izvor: UNWTOb

Na globalnoj razini povećanje broja posjetitelja ukazuje na povećanu liberalizaciju tržišta i dostupnost turističkih putovanja velikom broju ljudi. Upravo je masovnost turizma u novije vrijeme osnovni uzrok problema u brojnim destinacijama jer utječe na premašivanje kapaciteta nosivosti i na narušavanje odnosa između domaćina i gostiju (primjerice, Gursoy, Chi i Dyer, 2010; Wai Lai i Hitchcock, 2017; Hughes, 2018; Hernandez-Maskivker, Ferrari i Cruyt, 2019).

Trend povećanja broja međunarodnih turističkih dolazaka posljednjih je godina velikim dijelom pod utjecajem razvoja ekonomije dijeljenja, posebice Airbnb-ja. Problemi koje je uzrokovala ova platforma brojni su (npr. gentrifikacija, pretjeran rast turizma u destinacijama i u konačnici istiskivanje lokalnog stanovništva) i predmet su brojnih istraživanja (Goodwin, 2017; Peeters et al., 2018; Ioannides, Röslmaier i van der Zee, 2019; Oklevik et al., 2019). Neke od destinacija koje su počele nametati restrikcije budućem razvoju Ai- 
rbnb-ja su Berlin i Barcelona. Iako se u ekonomiji dijeljenja pojavljuju brojne platforme u okviru svih komponenti turističke ponude (npr. BlaBlaCar, Homeaway, CouchSurfing, itd.), Airbnb ima dominantnu ulogu u povećanju broja turističkih noćenja u destinacijama jer s jedne strane omogućava ulazak velikog broja smještajnih kapaciteta na tržište ponude, a s druge strane potrošači imaju puno veći izbor smještajnih kapaciteta u destinacijama, vrlo često po povoljnijim cijenama u odnosu na hotelski smještaj (Koens, Postma i Papp, 2018; Martín Martín, Guaita Martínez i Salinas Fernández, 2018; Gyódi, 2019; Gutiérrez-Taño, Garau-Vadell i Díaz-Armas, 2019; Namberger et al., 2019; Perkumienè i Pranskūnienè, 2019; Smith, Pinke Sziva i Olt, 2019; Moreno-Gil i Coca-Stefaniak, 2020; Nilsson, 2020). Stoga se i problemi uzrokovani ekonomijom dijeljenja u turizmu izučavaju dominantno kroz prizmu utjecaja Airbnb-ja na različite destinacije. Navedena dva čimbenika čine okosnicu za pojavu prekomjernog turizma u destinacijama, a zajedno s ostalim prethodno navedenim faktorima doveli su do značajnog premašivanja fizičkih, socioloških i kulturoloških kapaciteta brojnih destinacija diljem svijeta.

Izazovi, ili barem neki od njih, koji zahtijevaju rješavanje u kontekstu prekomjernog turizma su kompleksnost odnosa uključenih dionika, kulturne različitosti, klimatske promjene i administrativne strukture (Wall, 2019:39). Naime i prethodno spomenuti ključni faktori razvoja prekomjernog turizma proizlaze iz strategija rasta i razvoja usmjerenih prema masovnom turizmu. Upravo je to razlog zbog kojeg je potencijalne probleme, koji bi vrlo izgledno mogli nastati paralelno s tim razvojem, bilo vrlo pogodno i prigodno zanemariti na uštrb postizanja željenih rezultata. „Veći broj raspoloživih kreveta koji se mogu unajmiti po cijenama nižim od onih u hotelima jedan su od razloga zbog kojih se Airbnb može smatrati ključnim faktorom koji je doprinio pojavi prekomjernog turizma“ (Milivojević, 2019:20). Uz povećan broj niskotarifnih zračnih prijevoznika, širenje tržišta potražnje i ostale ekonomske i društvene pretpostavke širenja turističkog tržišta, ovaj koncept očekivano je dobio značajnu medijsku pažnju s jedne strane, ali i doživio otpor lokalnih dionika s druge strane. Naime, različite skupine dionika pod različitom su razinom utjecaja prekomjernog turizma te mu se različitim strategijama prilagođavaju. Stoga se u nastavku analiziraju upravo dionici destinacija kako bi se utvrdili njihovi interesi na razini destinacija, ali i potencijalni koraci u prevladavanju učinaka prekomjernog turizma.

\subsection{Uloga ključnih dionika na razini destinacije u prevladavanju učinaka prekomjernog turizma}

Ne umanjujući jačinu učinka koju prekomjerni turizam ima na zadovoljstvo turista u destinaciji i kvalitetu njihovog ukupnog doživljaja tijekom boravka, kao glavne skupine dionika koje su pod izravnim utjecajem ove pojave autori izdvajaju javni i privatni sektor te lokalno stanovništvo. Ove tri skupine izravno su povezane s problemom prekomjernog turizma, bilo da na njega djeluju kao uzrok ili da osjećaju njegove posljedice. Ipak, UNWTO definira pet skupina dionika na razini destinacije, a svaka skupina ima svoje dominantne interese koje pokušava realizirati.

Kod određenih skupina dionika dolazi do preklapanja interesa, što može olakšati, ali i značajno otežati njihovu realizaciju. Naime, prema Milivojeviću (2019:25), za uspješno prevladavanje učinaka prekomjernog turizma nužna je uključenost svih dionika turističke destinacije. Međutim, takvo rješenje pretpostavlja izrazito visoku razinu svijesti o važnosti 
Tablica 1. Skupine dionika - sastav i dominantni interesi

\begin{tabular}{|c|c|c|}
\hline Skupina dionika & Sastav & Dominantni interesi \\
\hline $\begin{array}{l}\text { Stanovnici i drugi } \\
\text { lokalni korisnici } \\
\text { destinacije }\end{array}$ & $\begin{array}{l}\text { - stalno stanovništvo } \\
\text { - povremeno stanovništvo } \\
\text { - osobe u tranzitu }\end{array}$ & $\begin{array}{l}\text { - kvaliteta života i dugoročnog } \\
\text { življenja } \\
\text { - zaštita i održavanje materijalne } \\
\text { i nematerijalne baštine (prirodne } \\
\text { i kulturne) } \\
\text { - pristup, kvaliteta i vrijednost } \\
\text { stanovanja } \\
\text { - zaštita i sigurnost } \\
\text { - zdravo i održivo okruženje } \\
\text { - jedinstvena dostupnost } \\
\text { - pristup i kvaliteta infrastrukture } \\
\text { i javnih usluga }\end{array}$ \\
\hline $\begin{array}{l}\text { Domaći i inozemni } \\
\text { posjetitelji }\end{array}$ & $\begin{array}{l}\text { - međunarodni i domaći turisti } \\
\text { - međunarodni i domaći izletnici }\end{array}$ & $\begin{array}{l}\text { - kvaliteta smještaja, proizvoda i } \\
\text { usluga } \\
\text { - vrijednost za novac } \\
\text { - zaštita i sigurnost } \\
\text { - zdravo i održivo okruženje } \\
\text { - jedinstvena dostupnost } \\
\text { - pristup i kvaliteta infrastrukture } \\
\text { i javnih usluga }\end{array}$ \\
\hline Poslovni subjekti & $\begin{array}{l}\text { - privatna poduzeća (npr. hoteli, } \\
\text { muzeji, turoperatori, ...) } \\
\text { - prijevoznici } \\
\text { - zaposlenici poduzeća koji su na } \\
\text { usluzi turistima (ali nisu nužno } \\
\text { primarno vezani uz turizam) }\end{array}$ & $\begin{array}{l}\text { - ekonomsko blagostanje i održi- } \\
\text { vost (velik povrat na investicije) } \\
\text { - održivost grada } \\
\text { - konkurentnost destinacije } \\
\text { - zaštita i sigurnost } \\
\text { - kvaliteta infrastrukture }\end{array}$ \\
\hline $\begin{array}{l}\text { Nositelji strategija i } \\
\text { DMO-i }\end{array}$ & $\begin{array}{l}\text { - nositelji strategija u turizmu } \\
\text { - druge javne ustanove } \\
\text { - destinacijske menadžment orga- } \\
\text { nizacije (DMO-i) }\end{array}$ & $\begin{array}{l}\text { - uravnotežen razvoj u svim seg- } \\
\text { mentima } \\
\text { - ekonomsko i društveno blagos- } \\
\text { tanje } \\
\text { - lokalni razvoj } \\
\text { - iskustvo posjetitelja }\end{array}$ \\
\hline $\begin{array}{l}\text { Dionici u širem } \\
\text { kontekstu }\end{array}$ & $\begin{array}{l}\text { - poduzeća nepovezana s turiz- } \\
\text { mom } \\
\text { - udruge građana } \\
\text { - udruge usmjerene na zaštitu } \\
\text { prirodne i kulturne baštine }\end{array}$ & $\begin{array}{l}\text { - kompleksna mješavina interesa, } \\
\text { ovisno o skupini dionika } \\
\text { - dugoročna održivost i } \\
\text { konkurentnost } \\
\text { - prihodi od poreza (na lokalnoj, } \\
\text { regionalnoj i nacionalnoj razini) }\end{array}$ \\
\hline
\end{tabular}

Izvor: UNWTO (2018:19). 
upravljanja turističkom destinacijom, ali istovremeno podrazumijeva zadovoljenje interesa svake skupine dionika, a ne nužno njihovu maksimizaciju. Iako je, kako je ranije navedeno, prekomjerni turizam situacija u kojoj lokalno stanovništvo izražava nezadovoljstvo, to isto stanovništvo nije nužno negativno usmjereno prema razvoju turizma u destinaciji. Termin učinak ponekad se koristi u pejorativnom značenju, ali stanovnici destinacije vrlo često priželjkuju dolazak većeg broja turista (Wall, 1996:207). Stoga se rješenje problema nazire u koordiniranim naporima svih dionika koji bi strategije razvoja turizma na području prilagodili objektivnim mogućnostima i potrebama destinacije.

U destinacijama u kojima dolazi do intenzivnog razvoja turizma i povećane interakcije između domaćina i gostiju, mogu se pojaviti novi obrasci ponašanja i potrošnje, što kod lokalne zajednice može izazvati tzv. turizmofobiju (npr., Huete i Mantecón, 2018; Almeida-García, Cortés-Macías i Balbuena-Vázquez, 2019; Fletcher et al, 2019; Pirillo Ramos i Mundet, 2020). Kasnije ta situacija može rezultirati povećanim tenzijama, nadmetanjem interesa i konfliktnim obrascima ponašanja na razini destinacije (Taş Gürsoy, 2019:434). Upravo u takvim situacijama do izražaja dolazi važnost koordinacije rada i interesa dionika turističke destinacije. Naime, interesi lokalnog stanovništva očituju se, kako je navedeno u Tablici 1, u povećanoj kvaliteti života odnosno održivijem životnom okruženju. Upravo iz tog razloga nužno je koordinirati interese svih dionika, a posebice one koji se dijelom preklapaju kod različitih skupina dionika (označeno u Tablici 1). Stoga se uloge različitih dionika u nastavku rada analiziraju na primjeru različitih destinacija suočenih s problemom prekomjernog turizma.

\subsection{Metodologija istraživanja}

Metodološki pristup odabran za ovo istraživanje je analiza studije slučaja. Ova metoda odabrana je kako bi se analizirali uzroci pojave prekomjernog turizma u odabranim turističkim destinacijama te kako bi se izdvojili ključni problemi uzrokovani pojavom prekomjernog turizma. Na temelju tih podataka cilj je istraživanja definirati one skupine dionika koje imaju ključnu ulogu u prevladavanju prekomjernog turizma te dati prijedlog potencijalnih načina rješavanja problema koji se javljaju razvojem prekomjernog turizma u destinacijama.

Za potrebe ovog istraživanja odabrane su destinacije Prag, New York i Luzern. Odabir ovih destinacija temelji se na činjenici da one nisu usporedive svojom površinom niti brojem stanovnika, što ih čini zanimljivima za istraživanje u ovoj studiji. Također, iako se uzroci prekomjernog turizma dijelom preklapaju kod sve tri odabrane destinacije, ipak su njihovi turistički proizvodi u svojoj osnovi različiti, što se dodatno naglašava kod svake destinacije.

\subsection{Manifestacija učinaka prekomjernog turizma na razini odabranih destinacija}

Iako je manifestacija učinaka prekomjernog turizma najuočljivija u urbanim sredinama, oni, naravno, nisu ograničeni isključivo na gradove. Međutim, upravo je u urbanim sredinama zabilježen najveći odjek učinaka prekomjernog turizma, a lokalno stanovništvo pokazuje otpor prema daljnjem razvoju (Goodwin, 2017; Kuščer i Mihalič, 2019; Nam- 
berger et al., 2019; Nilsson, 2020). Neuravnotežen razvoj turističkih destinacija, usmjeren isključivo na ekonomske učinke, može dovesti do poremećaja u ekosustavima ili gubitka autentičnosti destinacija (Benner, 2019:6). Kako je spomenuto ranije u radu, osnovni je preduvjet održivog razvoja turizma uravnotežen odnos svih njegovih načela - ekonomskog, ekološkog i socio-kulturnog. Bilo kakav poremećaj te ravnoteže odražava se na mogućnost očuvanja destinacija (Krajinović, 2015:68). Na razini gradova ta se ravnoteža odražava na mogućnost korištenja javne infrastrukture, prometnih linija, mogućnost korištenja usluga javnog sektora, učinkovitost javnih službi, kvalitetu života svih dionika i sl. Upravo iz tog razloga u radu se analiziraju tri gradske sredine koje bilježe različite faktore pojave prekomjernog turizma, ali svima su zajednički napori kojima pokušavaju iznaći načine prevladavanja njegovih posljedica.

\section{Prag}

Problematika koja se javlja u ovoj destinaciji vezana je uz prostorno opterećenje destinacije odnosno pritisak velikog broja korisnika na relativno malu površinu grada, odnosno na njegovu povijesnu jezgru. U Pragu je došlo do izrazite klasterizacije smještajnih objekata, a ne postoji niti disperzija sadržaja u širem središtu grada (Kádár, 2018; Ključnikov, Krajčík i Vincúrová, 2018; Hospers, 2019). Takva situacija omogućena je liberalizacijom zakonodavnog okvira, izgradnjom novih hotela i popratne infrastrukture, povećanim brojem zračnih linija, a posebice uvođenjem niskobudžetnih linija (Rončāk, 2019). Analogno prethodno navedenim faktorima koji su doveli do pojave prekomjernog turizma, moguće je zaključiti da su upravo niskobudžetne linije imale ključnu ulogu u iniciranju tog problema u ovoj destinaciji. Izrazita prostorna zasićenost ima utjecaj i na socio-kulturnu održivost destinacije jer je percepcija Praga vezana uz zabavu i noćni život (npr. Thurnell-Read, 2012). U tom se kontekstu snošljivost između turista i lokalnog stanovništva dovodi do granica izdržljivosti. Posljedice prekomjernog turizma u Pragu su prodiranje posjetitelja u stambene dijelove grada, velik broj turista u odnosu na broj stanovnika, egzodus lokalnog stanovništva, neprimjereno ponašanje i gentrifikacija (Peeters et al., 2018:203).

Najveći problemi koje je prekomjerni turizam uzrokovao u Pragu su prenatrpanost destinacije, transformacija jezgre Praga u komercijalizirani „turistički geto“, gubitak prihoda od poreza i naknada, povećanje cijena najma nekretnina i gubitak kvalitete života lokalnog stanovništva, povećana konkurentnost i manji prihodi (Rončák, 2019:159-162). Sve navedeno donekle je očekivana posljedica ovakvog razvoja turizma, a prethodno nekoordinirane strategije različitih skupina dionika dovele su do prevelikog broja turista koje je u ovim uvjetima nužno disperzirati na manje opterećene dijelove grada.

Strategije koje se koriste kako bi se prevladali učinci prekomjernog turizma i omogućili kvalitetniji životni uvjeti za lokalno stanovništvo su (UNWTO, 2019b:73-74):

- promicanje disperzije posjetitelja unutar grada i izvan njega

- ispitivanje i prilagodba propisa

- unaprjeđenje segmentacije posjetitelja

- kreiranje gradskih iskustava za stanovništvo i posjetitelje

- unaprjeđenje gradske infrastrukture i objekata te 
- određivanje mjera nadgledanja i očitovanja.

Najveći napori trebaju se uložiti u prostornu disperziju jer u određenim dijelovima grada postoji infrastruktura koja nije u potpunosti iskorištena, a može rasteretiti izrazito posjećeno gradsko središte i pozitivno djelovati na lokalnu zajednicu, ali i na doživljaj turista. Ovo rješenje ujedno je i najteže realizirati jer su turisti motivirani uglavnom posjećivanjem stare gradske jezgre, što rezultira paradoksom na razini destinacije.

\section{Luzern}

Turistima iz Azije, koji imaju najveći udio u ukupnoj strukturi inozemnih posjetitelja Luzerna, ovaj je grad poznat kao destinacija za kupnju, posebice nakita i satova. Upravo je iz toga razloga u Luzernu prisutan izrazit pritisak posjetitelja na malu jedinicu površine, koncentriranu na samo središte grada, ali i na jedinicu vremena, jer se turisti zadržavaju vrlo kratko i u tom vremenu pokušavaju sa sobom ponijeti što je više moguće suvenira, dok istovremeno nisu usmjereni na ostale dijelove grada koje bi mogli posjetiti i razgledati (UNWTO, 2019b:61). Iako se uzroci prekomjernog turizma u Pragu i Luzernu dijelom preklapaju, potonji je pod dodatnim pritiskom kratkog boravka turista, ali i njihovih navika za vrijeme putovanja. Jedan od faktora nastanka ove pojave je otvaranje i intenzivan rast novih tržišta, posebice onih iz azijske regije (npr. Frank, 2016). Naime, u Luzernu velik broj turističkih autobusa ometa lokalni promet, a dominacija grupnih putovanja promijenila je strukturu trgovina u starom gradu, što je utjecalo na kvalitetu života stanovnika grada i dovela do negodovanja na lokalnoj razini. Lokalni stavovi prema masovnom turizmu postaju izrazito neprijateljski, a od gradskih je vlasti zatraženo intenzivnije rješavanje ovog problema (Weber et al., 2019:169; Dodds i Butler, 2019).

Kao glavne učinke prekomjernog turizma u Luzernu moguće je izdvojiti sve veći broj grupa turista iz Azije, zagušenje prometnica i javnog prijevoza, velik broj turista u odnosu na broj stanovnika, istiskivanje tradicionalnih obrta i povećanje razine cijena (Peeters et al., 2018:192). Sposobnost destinacije da se prilagodi novim tržišnim uvjetima izravno ovisi o motivaciji i uključenosti različitih skupina dionika. Moguće je zaključiti da je prekomjerni turizam u Luzernu rezultat ne samo velikog broja turista, već i njihovih navika ponašanja na putovanju. Stoga strategije prilagodbe trebaju biti usmjerene upravo na navedene probleme kako bi ih se što uspješnije prevladalo za dobrobit lokalne zajednice. Jedno od potencijalnih rješenja svakako je usmjerenost na novi ciljni segment odnosno na individualne turiste. Njihovo je kretanje destinacijom puno jednostavnije disperzirati jer ne ovise o efektu gomile, a i sam način putovanja može značiti da su oni manje skloni masovnom turizmu i kretanju u velikim skupinama. Moguće je tvrditi da bi privlačenjem ovog segmenta došlo do barem djelomičnog rasterećenja najposjećenijih dijelova destinacije.

\section{New York}

Ova je destinacija u posljednje vrijeme također pod utjecajem prekomjernog turizma. Posljednjih je godina prekomjerni turizam u ovom gradu reflektiran kroz nekoliko posljedica: pretrpane šetnice, manjak parkirnih mjesta za autobuse, velik pritisak na podzemnu željeznicu i istiskivanje stanovništva iz središta grada na uštrb razvoja Airbnb-a (UNWTO, 
2019b:67). Unatoč velikoj površini i stoga manje očekivanom razvoju ove pojave, i ova je urbana sredina predmet istraživanja posljedica prekomjernog turizma.

Iako se organizacije turizma u svakoj od analiziranih destinacija razlikuju, dionici unatoč tome djeluju koordinirano i nastoje prevladati nastale izazove. Mjere koje dionici ove destinacije implementiraju kako bi prevladali nastale probleme su (UNWTO, 2019b:68-69):

- promicanje disperzije posjetitelja unutar grada i izvan njega

- promicanje vremenske disperzije posjetitelja

- stimuliranje novih itinerara i atrakcija

- ispitivanje i prilagođavanje propisa

- unaprjeđivanje segmentacije posjetitelja

- kreiranje gradskih iskustava za stanovništvo i posjetitelje

- unaprjeđenje gradske infrastrukture i objekata te

- komuniciranje i uključivanje lokalnih dionika.

Unatoč tome što su teško neusporedivi veličinom, Prag i New York se s ovom pojavom nose gotovo identičnim strategijama, koje su uglavnom usmjerene na disperziju turističkog prometa na šire gradsko središte i time nastoje jednakomjernije rasporediti opterećenost javne i prateće infrastrukture, uravnotežiti odnos između domaćina i gostiju te kao konačni cilj omogućiti kvalitetu života lokalnoj zajednici.

Kako je ranije utvrđeno u radu, prekomjerni turizam se kao pojava ne može analizirati samo korištenjem kvantitativnih pokazatelja, već je nužno uključiti i kvalitativne elemente. No radi lakšeg razumijevanja pritiska razvoja turizma na te destinacije, u Tablici 2 daje se pregled broja stanovnika analiziranih destinacija, broj turističkih dolazaka te se daje omjer broja stanovnika i turista radi boljeg razumijevanja.

Tablica 2. Pokazatelji razvoja turizma u analiziranim destinacijama u 2018. i 2019. godini

\begin{tabular}{|l|c|c|c|}
\hline Grad & Broj stanovnika & $\begin{array}{c}\text { Broj turističkih } \\
\text { dolazaka }\end{array}$ & $\begin{array}{c}\text { Broj turista / broj } \\
\text { stanovnika }\end{array}$ \\
\hline Prag & 1.298 .804 & 8.044 .324 & 6,2 \\
\hline Luzern & 57.066 & NA* $^{*}$ & $/$ \\
\hline New York & 8.361 .043 & 10.931 .000 & 1,3 \\
\hline
\end{tabular}

Izvor: World Population Review, Prague City Tourism, NYCdata.

* Za Luzern nisu dostupni podaci o broju dolazaka turista, dostupni su podaci o noćenjima i broj posjetitelja u regiji, što nije usporedivo s podacima za ostale destinacije te su stoga ti podaci isključeni iz analize. Samo kao ilustracija veličine turističkog prometa u toj regiji, u 2015. godini zabilježeno je 12 milijuna dnevnih posjetitelja (Lucerne, 2020).

Iz analiziranih podataka može se zaključiti da je omjer broja posjetitelja i broja stanovnika u Pragu izrazito nepovoljan, dok je u New Yorku on ipak povoljniji. To, međutim nije bezuvjetna pretpostavka povoljnog razvoja turizma u gradu, a što je jasno iz prethodne analize. Sukladno svemu navedenom, u nastavku se analiziraju one skupine dionika koje su ključne u prevladavanju akumuliranih problema nastalih prekomjernim turizmom u navedenim destinacijama. 


\section{MOGUĆNOSTI PREVLADAVANJA UČINAKA PREKOMJERNOG TURIZMA NA RAZINI DESTINACIJA}

Unatoč činjenici da prekomjerni turizam nije pojava novijeg datuma, dionici destinacija tek se odnedavno aktivnije uključuju u rješavanje izazova koje ova pojava sa sobom nosi (Avond et al., 2019; Dodds i Bulter, 2019; Nilsson, 2020; Wall, 2020). Međutim, neke od skupina dionika problemu još uvijek pristupaju samo na deklarativnoj razini, ne razumijevajući ili ne prihvaćajući u potpunosti svoju ulogu u ovom procesu. Općenito je moguće tvrditi da su ključne smjernice za prevladavanje problema prekomjernog turizma sljedeće (Jamieson i Jamieson, 2019:220):

- promjena načina razmišljanja o onima koji su zaduženi za upravljanje razvojem turizma u destinacijama

- razvoj boljeg razumijevanja naravi destinacija

- upravljanje prekomjernim turizmom u kontekstu destinacija

- ocjena uloge destinacijskih marketinških (ili menadžment) organizacija u upravljanju prekomjernim turizmom

- prepoznavanje uloge lokalne vlasti u prevladavanju prekomjernog turizma i

- bolje upravljanje posjetiteljima u destinacijama.

Učinke prekomjernog turizma moguće je prevladati uz pomoć strategija koje će biti implementirane prije promocije, mjerenja učinaka, novih partnerstava i mehanizama financiranja (Becken i Simmons, 2019:243). U tom procesu ključnu ulogu imaju dionici destinacija koji različitim metodama pokušavaju zadovoljiti svoje interese, ali bi istovremeno trebali biti usmjereni na rješavanje problema prekomjernog turizma u destinacijama. Ovdje ključnu ulogu svakako ima destinacijski menadžment kao integrirani proces upravljanja destinacijom, a koji uključuje četiri elementa - ponudu destinacije, posjetitelje, marketinšku komunikaciju i organizacijsku odgovornost (Anderson, 2001:146). U okviru destinacijskog menadžmenta donose se ključne odluke o načinu upravljanja destinacijom, a dobro definirane i implementirane strategije omogućavaju sveobuhvatno razumijevanje i rješavanje problema prekomjernog turizma u određenoj destinaciji. Štoviše, destinacijski menadžment ne gubi svoju važnost u kontekstu suvremenog razvoja turizma, ali nužno mora transformirati svoj osnovni zadatak - povećanje konkurentnosti i razvoj destinacije (Eckert et al., 2019:651).

Na temelju podataka navedenih u Tablici 1 , ovo istraživanje usmjereno je na tri skupine dionika - javni sektor (koji uključuje nositelje strategija i DMO-e), privatni sektor (odnosno poslovne subjekte) i lokalno stanovništvo (odnosno stanovnike i druge lokalne korisnike destinacije). Dionici u širem kontekstu, koji se navode u tablici, po svojoj su definiciji raspoređeni na privatni i javni sektor odnosno na lokalno stanovništvo. Njihova karakteristika je razina uključenosti u razvoj turizma na području destinacije odnosno oni nemaju nužno izravan interes od razvoja turizma, ali svakako u kontekstu prekomjernog turizma osjećaju posljedice neodrživog razvoja turizma. Inozemni i domaći posjetitelji izostavljeni su iz ove analize. Naime, uloga turista je u ovom procesu ključna, ali pojedina istraživanja (npr. Jover i Díaz-Parra, 2020; Nilsson, 2020) dokazuju da se uzroci prekomjernog turizma u velikoj mjeri mogu i moraju rješavati na razini destinacija, prilagodbom planova razvoja turizma. Stoga su turisti kao skupina dionika i kao korisnici turističkih proizvoda i usluga 
u destinaciji svakako važni, ali se ponekad njihova uloga u razvoju prekomjernog turizma predimenzionira pa se ova analiza temelji samo na trima ključnim skupinama dionika.

\subsection{Uloga javnog sektora}

U brojnim situacijama planiranje i upravljanje turizmom na lokalnoj razini, uključujući i pitanje prekomjernog turizma, može biti dio lokalne politike koja ima mogućnost donošenja propisa i potrebne vještine za omogućavanje održivog razvoja turizma (Jamieson i Jamieson, 2019:225). Naime, unatoč tome što turizam velikim dijelom ovisi o poslovnim subjektima odnosno o privatnom sektoru, ipak se javni sektor aktivno uključuje u razvoj donošenjem strategija i provedbom strateških ciljeva. Javni i privatni sektor imaju bitno različite interese u ovom procesu (Tablica 1) i stoga je važno imati jasno definirane ciljeve koji se namjeravaju postići. Unatoč činjenici da destinacije uglavnom imaju strategije koje pretpostavljaju razvoj u skladu s načelima održivog razvoja turizma, nisu sve strategije implementirane i ne provode se kvalitetno ili se ne provode uopće. U tom je dijelu ključna uloga upravo javnog sektora i to na razini destinacije jer na toj razini nositelji strategije imaju jasan pregled nad problemima i mogućnostima destinacije i svih ostalih njenih dionika.

Iako svaki dionik ima svoju jasno definiranu ulogu u procesu prevladavanja učinaka prekomjernog turizma, njihove se uloge dijelom preklapaju, jednako kao što su i njihovi interesi dijelom sinkronizirani. Stoga problemi nastaju upravo u situaciji kada različiti dionici maksimiziraju svoje interese ne obazirući se na druge dionike, kao ni na društvenu dobrobit. Kako bi se izbjegli suprotstavljeni učinci turizma i negativna percepcija lokalnog stanovništva, nositelji strategija moraju bolje surađivati s lokalnom zajednicom (UNWTO, 2018:20).

U ovom procesu javlja se i problem povezanosti javnog i privatnog sektora, što rezultira situacijom u kojoj lokalni političari, umjesto da traže tehnička rješenja ili potiču pregovore dionika oko premošćivanja nastalih problema, pokušavaju izbjeći nastalu situaciju (Pinke-Sziva et al., 2019:12). U različitim destinacijama javljaju se pozitivni primjeri uključenosti javnog sektora u rješavanje ovog problema, poput zatvaranja otoka Boracay za turiste, gdje se pokušava privremenim zatvaranjem sustava dati prirodi priliku za regeneraciju (Cruz i Legaspi, 2019). Nadalje, u Barceloni su jasno definirani ključni aspekti prevladavanja problema prekomjernog turizma u kojima dominantnu ulogu ima javni sektor i to u okviru (Goodwin, 2019:133):

- upravljanja (jačanje suradnje među dionicima)

- znanja (za uspješno donošenje odluka i upravljanje)

- destinacije (disperzija kretanja turista gradom)

- mobilnosti (korištenje pametne tehnologije) te

- smještaja (rješavanje problema prevelikog broja kapaciteta u pojedinim dijelovima grada, kao i rješavanje problema nekategoriziranih kapaciteta).

Važno je napomenuti da je, analogno konceptu održivog razvoja turizma, i prekomjerni turizam dijelom pitanje političke volje. Naime, Wall (1997:33) tvrdi da je održivi razvoj prije svega politički slogan, a u manjoj mjeri je on analitički alat te ga se stoga može promatrati kao katalizator za raspravu, kompromis i identifikaciju primjerenog balansa između sukobljenih interesa. Stoga se čini da je u i procesu prevladavanja problema prekomjernog 
turizma volja javnog sektora od ključne važnosti, posebice zbog toga što neke odluke može donijeti samo javni sektor zbog činjenice da turističku ponudu dijelom čine javnog dobra (poput privremenog zatvaranja otoka Boracay, Filipini ili uvale Maya Bay, Tajland). Pitanje učinkovitosti tih mjera tek će se moći raspravljati jer je interes turista za posjećivanjem tih lokaliteta i dalje prisutan pa će biti nužno pratiti hoće li nakon njihovog ponovnog otvaranja pritisak turista biti na jednakoj razini. Međutim, odlučnost javnog sektora je svakako prisutna i rezultirala je povoljnim mjerama za ekosustav i lokalno stanovništvo, barem u kratkom roku.

Na primjeru prethodno analiziranih destinacija, uloga javnog sektora očituje se u sljedećem:

1) Prag - prostorna disperzija posjetitelja, segmentacija tržišta, poboljšanje infrastrukture, razvijanje sustava za praćenje utjecaja posjetitelja na destinaciju

2) Luzern - prostorna disperzija posjetitelja, stimuliranje razvoja novih atrakcija

3) New York - prostorna i vremenska disperzija posjetitelja, stimuliranje razvoja novih atrakcija, segmentacija tržišta, unaprjeđenje infrastrukture, razvijanje sustava za praćenje utjecaja posjetitelja na destinaciju.

Vidljivo je da se uloga javnog sektora dijelom preklapa u svim analiziranim destinacijama, samo je pitanje koje će se točno metode prilagodbe i primjene strategija primijeniti. Na primjeru destinacija analiziranih u radu zaključak je autora da je uloga javnog sektora ključna u Pragu jer je nužno, osim disperzije turističkog prostora, uložiti napore i u jačanje imidža destinacije koji će biti odmaknut od zabave i noćnog života kako bi se privukli oni segmenti turističke potražnje koji će imati manje učinaka na smanjenje kvalitete života lokalnog stanovništva.

\subsection{Uloga privatnog sektora}

Uloga privatnog sektora nije problematična samo u kontekstu prekomjernog turizma, već se interes privatnog kapitala analizira u različitim kontekstima razvoja turizma. Naime, posebice kada su u pitanju strana ulaganja u destinaciju, privatni sektor ima gotovo isključivo interes postizanja povrata na ulaganje i dugoročne ekonomske koristi. Poteškoće u destinacijama, koje se manifestiraju prevelikim brojem posjetitelja, velikim su dijelom inicirane suvremenim poslovnim modelima, poput Ubera ili ranije analiziranog Airbnb-a. Upravo je iz tog razloga ulogu privatnog sektora nužno dobro definirati i njihove interese zadovoljiti na način da se ne naruši održivost destinacije.

Jedan od načina za aktivnije uključivanje privatnog sektora je jačanje onih njihovih interesa i ciljeva koji su zajednički nekim drugim dionicima (Tablica 1). Većina analiziranih primjera, naravno, usmjerena je upravo na analizu uloge privatnog sektora jer su oni ključni suradnici javnog sektora u tom procesu. Na primjeru prethodno analiziranih destinacija, uloga privatnog sektora očituje se u sljedećem:

1) Prag - prilagođavanje regulacije tržišta

2) Luzern - promicanje vremenske disperzije posjetitelja razvojem novih proizvoda, segmentacija tržišta

3) New York - promicaanje vremenske disperzije posjetitelja, prilagođavanje regulacije, segmentacija tržišta, kreiranje novih iskustava. 
Sve navedene uloge definirane su s ciljem segmentacije tržišta i disperzije turističkog prometa, što bi lokalnim poduzećima osiguralo dugoročnu održivost na tržištu. Primjerice, jedan od problema prekomjernog turizma u Veneciji je istiskivanje tradicionalnih obrta iz središta grada u korist standardiziranih usluga (Nolan i Séraphin, 2019). Na primjeru analiziranih destinacija moguće je zaključiti da je u prevladavanju problema prekomjernog turizma u Luzernu ključna upravo uloga privatnog sektora. Naime, iako je dominantno problem vezan uz jednodnevne posjetitelje, ipak bi privatni sektor svojom ponudom mogao disperzirati turistički promet, preusmjeravajući veliki broj turista iz male gradske jezgre, kao i omogućavanjem optimalnog doživljaja turistima koji su motivirani kulturnom ponudom ove destinacije.

\subsection{Uloga lokalnog stanovništva}

Percepcija lokalnog stanovništva o učincima turizma ovisi o uvjetima na tržištu i brojnim drugim faktorima (Muler Gonzalez, Coromina i Galí, 2018:281). Među lokalnim stanovništvom postoje skupine koje imaju izravne koristi od razvoja turizma jer su i dio privatnog sektora, ali postoje i one skupine koje nemaju te koristi odnosno njihova se korist očituje neizravno, u poboljšanju kvalitete javne infrastrukture, povećanju kvalitete života i blagostanja na razini destinacije (Tablica 1). Stoga je očekivano da će i tolerancija prema turistima između ove dvije skupine biti različita odnosno da sklonost razvoju turizma neće biti jednaka.

Iako pojam prekomjernog turizma preuzima gotovo u potpunosti negativno značenje, on zapravo predstavlja onu točku rasta turizma u kojoj odnos između domaćina i gostiju postaje nesnošljiv. Dakle, lokalno stanovništvo nije nužno a priori protiv razvoja turizma, ali pokazuje otpor prema nekontroliranom rastu koji nije usklađen s principima održivog razvoja turizma. Usmjerenost na rast kvantitativnih pokazatelja turizma, uglavnom na porast broja turističkih dolazaka, više nije poželjan cilj lokalnih zajednica (Benner, 2019:2).

Prema istraživanju koje je proveo UNWTO (2018:23), lokalno stanovništvo kao pozitivne učinke razvoja turizma izdvaja internacionalizaciju, povećanje broja događanja, pozitivniji imidž, zaštitu povijesne baštine, obnovu tradicionalne arhitekture, povećanje broja radnih mjesta u sezoni, veću ponudu kulturnih sadržaja, povećanje broja smještajnih kapaciteta, veće mogućnosti za razmjenu znanja te poboljšane uvjete života. Istovremeno, kao negativni učinci navode se povećanje razine cijena najma nekretnina, privatnih kuća, taksi usluga, javnog prijevoza, u trgovinama, u restoranima i kafićima, manje opcija za stanovanje, preopterećenost javnog prijevoza, zagađenje, buka te prevelika opterećenost šetnica i javnih površina.

Imajući u vidu ranije spomenutu činjenicu da lokalno stanovništvo u turizmu ne vidi isključivo ekonomsku korist, već mogućnost podizanja ukupne kvalitete života, nužno je osigurati optimalne uvjete za povećanje blagostanja. Na primjeru prethodno analiziranih destinacija, uloga lokalnog stanovništva očituje se u sljedećem:

1) Prag - uključivanje u disperziju turista unutar i izvan grada

2) Luzern - uključenost u razvoj novih proizvoda i poticanje disperzije turističkog prometa

3) New York - stimuliranje iznajmljivanja bicikala, uključivanje u kampanju „Vidi svoj grad“" s ciljem poboljšanja suradnje s javnim i privatnim sektorom. 
Od lokalnog se stanovništva, dakle, očekuje aktivno uključivanje u rješavanje problema prekomjernog turizma, prije svega rješavanjem problema disperzije turista. To se svakako može postići razvojem novih proizvoda koji će biti prisutni izvan središta grada, koji u svim analiziranim destinacijama predstavlja središte interesa turista. U konačnici, moguće je zaključiti da je lokalno stanovništvo ključna skupina dionika u New Yorku odnosno njihovi napori mogli bi biti ključni u prevladavanju problema prekomjernog turizma. Naime, moguće je očekivati da će upravo njihova uključenost pozitivno djelovati na suradnju privatnog i javnog sektora. Slični su slučajevi, a što je ranije analizirano u radu, zabilježeni u Veneciji i Barceloni, gdje je angažman lokalnog stanovništva podignuo razinu svijesti o utjecaju prekomjernog turizma i poduzimanje određenih akcija.

\subsection{Prijedlozi potencijalnih rješenja za upravljanje prekomjernim turizmom u destinacijama}

Na temelju provedenog istraživanja moguće je utvrditi da se pitanje prekomjernog turizma zasigurno neće riješiti bez intenzivne i kvalitetne suradnje između svih dionika destinacije. Avond et al. (2019:562) navode da je nužno postići okruženje na razini destinacije u okviru kojeg će svi dionici biti u mogućnosti optimizirati svoje interese i na taj način biti spremni na suradnju. Neki od potencijalnih rješenja za prevladavanje učinaka prekomjernog turizma koje navode su podizanje razine cijena (tu se prije svega misli na cijene ulaznica za posjetu različitih resursa u destinaciji), restriktivne kvote (ograničenja broja posjetitelja) ili različite kazne za kršenje nametnutih restrikcija. Ovo su mjere koje se smatraju manje poželjnima jer u sebi sadrže elemente prisile odnosno restrikcija, ali u uvjetima smanjene kvalitete života lokalnog stanovništva i iskustva turističkih posjetitelja, koji su potencirani razvojem prekomjernog turizma, restriktivne mjere su ponekad nužne.

S druge strane, Wall (2020) predlaže izravne i neizravne tehnike upravljanja posjetiteljima u destinaciji. Izravne tehnike pretpostavljaju suglasnost posjetitelja, dok se neizravnim tehnikama pokušava suptilno utjecati na ponašanje posjetitelja. Pregled tehnika daje se u Tablici 3.

Tablica 3. Odabrani načini upravljanja posjetiteljima u destinaciji

\begin{tabular}{|c|c|}
\hline Izravni & Neizravni \\
\hline $\begin{array}{l}\text { Nametanje, odnosno naplaćivanje } \\
\text { ulaznica } \\
\text { Ograničavanje aktivnosti/opreme } \\
\text { Nametanje uvjeta za sudjelovanje, } \\
\text { npr. dozvole i licence } \\
\text { Nametanje pravila i regulacija } \\
\text { Određivanje lokacija za specifične } \\
\text { aktivnosti, npr. kampiranje } \\
\text { Povećanje prisutnosti menadžmenta, } \\
\text { npr. više zaposlenika, nadzor }\end{array}$ & $\begin{array}{l}\text { Varijacija jednostavnosti pristupa } \\
\text { Dizajn i manipulacija lokalitetom } \\
\text { Vrsta i stupanj održavanja } \\
\text { Pružanje informacija } \\
\text { Obrazovanje u okviru okoliša/interpretacija } \\
\text { Zoniranje } \\
\text { Provođenje istraživanja } \\
\text { Limitiranje pomoćnih sadržaja, poput } \\
\text { parkirnih mjesta i smještajnih kapaciteta }\end{array}$ \\
\hline
\end{tabular}

Izvor: Wall, 2020. 
Upravljanje posjetiteljima najučinkovitije se postiže naplaćivanjem ulaznica te regulacijom ulaska posjetitelja (u Hrvatskoj bi primjer svakako bio Nacionalni park Plitvička jezera koji je korištenjem ovih tehnika počeo djelovati na masovnost posjeta u Parku). Izravnim tehnikama pokušava se postići neposredno djelovanje odnosno rezultati se mogu očekivati u kratkom roku. Za neizravne tehnike potrebna je određena razina edukacije, ali se na posjetitelje pokušava djelovati na način da ih se već samom ponudom pokušava demotivirati na posjećivanje (primjer limitiranog broja parkirnih mjesta, što svakako smanjuje stupanj zadovoljstva posjetitelja).

Prema Becken i Simmonsu (2019:239-240), uloge koje dionici imaju u kreiranju proizvoda općenito, a zatim i u prevladavanju učinaka prekomjernog turizma su sljedeće: vlast na nacionalnoj razini (npr. ministarstvo turizma) - razvoj strategija i propisa; nacionalna turistička organizacija - marketing (obično nacionalni); vlast na lokalnoj razini (npr. lokalno vijeće) - planiranje na lokalnoj razini, dobrobit lokalne zajednice; inozemni investitori - osiguravanje kapitala; zračni prijevoznici i zračne luke - omogućiti pristup destinacijama; velike (nacionalne) kompanije - proizvoditi usluge; manja (lokalna) poduzeća u turizmu proizvoditi usluge; udruženja na nacionalnoj razini - zastupati interese turizma; regionalne organizacije - marketing; zajednica - domaćini, investitori, zaposlenici; nevladine udruge - zagovarati očuvanje; te posjetitelji - uživanje ili druge vrijednosti. Ovako jasno definirane uloge omogućavaju bolji učinak pojedinih skupina dionika i optimizaciju njihovih interesa.

Na temelju provedenog istraživanja moguće je zaključiti da je prekomjerni turizam pojava kojom se danas tek pokušava upravljati, a destinacije nisu još u potpunosti uspjele iznaći rješenje koje bi dugoročno moglo osigurati pozitivan učinak. Među potencijalnim rješenjima koje većina destinacija pokušava implementirati su svakako disperzija turističkog prometa (vremenski i prostorno), segmentacija tržišta, diversifikacija proizvoda, razvoj infrastrukture koja će omogućiti disperziju prometa, marketinške aktivnosti koje su usmjerene na promociju turističkih sadržaja izvan gradske jezgre i slično. Jedan od primjera kako se diversifikacijom proizvoda pokušava disperzirati turistički promet je Barcelona koja razvija filmski turizam i na taj način privlači jedan specifičan segment turista u dijelove grada koji nisu u tolikoj mjeri pod pritiskom razvoja turizma (Martin-Fuentes et al., 2020). Buduća istraživanja u ovom području moraju biti usmjerena prema suradnji svih dionika destinacije, ali i prema definiranju jasnih smjernica za prevladavanje specifičnih grupa problema uzrokovanih prekomjernih turizmom, od kojih su neki analizirani u ovom radu. Konačni rezultat svih ovih napora bio bi sustav za mjerenje učinaka prekomjernog turizma na razini destinacije i set mjera kojima bi se ti učinci ublažili u dugom roku, uvažavajući načela održivog razvoja turizma.

\section{ZAKLJUČAK}

Na temelju analize provedene u ovom radu moguće je dati odgovore na postavljena istraživačka pitanja. Između brojnih čimbenika nastanka prekomjernog turizma, autori su poseban naglasak stavili na povećanje turističkog prometa odnosno rast međunarodnih turističkih dolazaka u posljednjih 70 godina. Taj trend rasta omogućio je masovnost turizma i pritisak velikog broja turista na pojedine destinacije. Drugi čimbenik koji je izdvojen i analiziran u radu je pojava ekonomije dijeljenja koja u svojoj osnovi pretpostavlja da se dobra ne 
moraju nužno posjedovati da bi se mogla konzumirati, a u turizmu ona pretpostavlja da se povećava količina i kvaliteta opcija za korištenje različitih usluga i dobara. Konkretno, Airbnb kao platforma za iznajmljivanje smještaja svakako je utjecala na pojavu prekomjernog turizma jer se sve veći broj smještajnih kapaciteta uključuje na stranu turističke ponude, što posljedično vrlo često uzrokuje pojavu gentrifikacije u turizmu.

Nakon analize tri studije slučaja - Praga, Luzerna i New Yorka, autori su došli do zaključka da je u svakoj od ovih destinacija, ovisno o manifestaciji i opsegu problema uzrokovanih prekomjernim turizmom i jačinom njegovih učinaka na, prije svega, lokalno stanovništvo, moguće izdvojiti onu skupinu dionika koja bi trebala biti ključna u rješavanju tih problema. Različitim strategijama, poput disperzije turističkog prometa, kako vremenskom tako i prostornom, segmentacijom tržišta, upravljanjem posjetiteljima, naplaćivanjem ulaznica, restrikcijom ulaska na lokalitete, marketinškim aktivnostima usmjerenim na određene segmente potrošača i sličnim strategijama, moguće je očekivati postupno rješavanje nastalih problema. Prekomjerni turizam pojava je s kojom će se destinacije morati naučiti nositi, istovremeno prihvaćaju da ju možda neće moći u potpunosti eliminirati. U konačnici, razvojem strategija za prevladavanje ili barem ublažavanje posljedica prekomjernog turizma moguće je očekivati umanjenje njegovih učinaka na razini turističkih destinacija.

Ograničenje ovog istraživanja ogleda se u korištenju studije slučaja kao metodološkog pristupa. Stoga se kao mogućnost unaprjeđenja ove studije izdvaja provođenje primarnog istraživanja u nekoj od destinacija u Hrvatskoj koje su suočene s problemom prekomjernog turizma (tu se, prije svega, misli na Dubrovnik i Nacionalni park Plitvička jezera), a to istraživanje nužno mora uključiti sve analizirane skupine dionika u okviru te destinacije, uključujući i turiste koji kao korisnici turističkih proizvoda i usluga imaju izravan utjecaj na kvalitetu resursa i na održivost razvoja turizma u tim destinacijama.

\section{LITERATURA:}

1. Almeida-García, F., Cortés-Macías, R., Balbuena-Vázquez, A. (2019). Tourism-phobia in historic centres: the case of Malaga. Boletín de la Asociación de Geógrafos Españoles, 83, 2823, 1-32. DOI: 10.21138/bage.2823

2. Anderson, D. (2001). Destination management. U Jafari, J. (ur). Encyclopedia of tourism. New York: Routledge. str. 146

3. Avond, G., Bacari, C., Limea, I., Seraphin, H., Gowreesunkar, V., Mhanna, R. (2019). Overtourism: a result of the Janus-faced character of the tourism industry. Worldwide Hospitality and Tourism Themes, 11(5), 552-565. DOI: 10.1108/WHATT-06-2019-0039

4. Becken, S., Simmons, D. G. (2019). Stakeholder management: different interests and different actions. U R. Dodds i R. W. Butler (ur.) Overtourism: Issues, Realities and Solutions. Boston: De Gruyter. str. 234-249. DOI: 10.1515/9783110607369-016

5. Benner, M. (2019). From overtourism to sustainability: A research agenda for qualitative tourism development in the Adriatic. MPRA Paper No. 92213. Preuzeto s https:// mpra.ub.uni-muenchen.de/92213/1/MPRA_paper_92213.pdf (13.11.2019.) 
6. Butler, R. W. (1980). The concept of a tourist area cycle of evolution: implications for management of resources. The Canadian Geographer, 24(1), 5-12. DOI: 10.1111/ j.1541-0064.1980.tb00970.x

7. Capocchi, A., Vallone, C. Pierotti, M., Amaduzzi, A. (2019). Overtourism: A Literature Review to Assess Implications and Future Perspectives. Sustainability, 11(12), 3303. DOI: $10.3390 /$ su11123303

8. Cruz, R. G., Legaspi, G. F. A. (2019). Boracay beach closure: the role of the government and the private sector. U R. Dodds i R. W. Butler (ur.) Overtourism: Issues, Realities and Solutions. Boston: De Gruyter. str. 95-110. DOI: 10.1515/9783110607369-007

9. Dodds, R., Butler, R. (2019). The phenomena of overtourism: a review. International Journal of Tourism Cities, 5(4), 519-528. DOI: 10.1108/IJTC-06-2019-0090

10. Dodds, R., Butler, R. W. (ur.) (2019). Overtourism: Issues, Realities and Solutions. Boston: De Gruyter. DOI: 10.1515/9783110607369-001

11. Doxey, G. (1975). A causation theory of visitor-resident irritants: methodology and research inferences in the impact of tourism. Sixth Annual Conference Proceedings of the Travel Research Association. San Diego, California.

12. Eckert, C., Zacher, D., Pechlaner, H., Namberger, P., Schmude, J. (2019). Strategies and measures directed towards overtourism: a perspective of European DMOs. International Journal of Tourism Cities, 5(4), 639-655. DOI: 10.1108/IJTC-12-2018-0102

13. Fletcher, R., Murray Mas, I., Blanco-Romero, A., Blázquez-Salom, M. (2019). Tourism and degrowth: an emerging agenda for research and praxis. Journal of Sustainable Tourism, 27(12), 1745-1763. DOI: 10.1080/09669582.2019.1679822

14. Frank, S. (2016). Dwelling-in-motion: Indian Bollywood tourists and their hosts in the Swiss Alps. Cultural Studies, 30(3), 506-531. DOI: 10.1080/09502386.2015.1113637

15. Goodwin, H. (2017). The Challenge of Overtourism. Responsible Tourism Partnership Working Paper 4. Preuzeto s https://haroldgoodwin.info/pubs/RTP'WP4Overtourism01'2017.pdf (13. 11. 2019.).

16. Goodwin, H. (2019). Barcelona - crowding out the locals: a model for tourism management? U R. Dodds i R. W. Butler (ur.) Overtourism: Issues, Realities and Solutions. Boston: De Gruyter. str. 125-138. DOI: 10.1515/9783110607369-009

17. Google Scholar (2019a). Preuzeto s https://scholar.google.com/scholar?q=overtourism\&hl=en\&as_sdt $=0 \% 2 C 5 \& a s \_y l o=2010 \&$ as_yhi $=2016$ (28. 12. 2019.).

18. Google Scholar (2019b). Preuzeto s https://scholar.google.com/scholar?q=overtourism\&hl=en\&as_sdt=0\%2C5\&as_ylo=2010\&as_yhi=2019 (28. 12. 2019.).

19. Gursoy, D., Chi, C. G., Dyer, P. (2010). Locals' Attitudes toward Mass and Alternative Tourism: The Case of Sunshine Coast, Australia. Journal of Travel Research, 49(3), 381-394. DOI: $10.1177 / 0047287509346853$

20. Gutiérrez-Taño, D., Garau-Vadell, J. B., Díaz-Armas, R. J. (2019). The Influence of Knowledge on Residents' Perceptions of the Impacts of Overtourism in P2P Accommodation Rental. Sustainability, 11(4), 1043. DOI: 10.3390/su11041043

21. Gyódi, K. (2019). Airbnb in European cities: Business as usual or true sharing economy? Journal of Cleaner Production, 221, 536-551. DOI: 10.1016/j.clepro.2019.02.221 
22. Hernandez-Maskivker, G., Ferrari, S., Cruyt, A. N. J. (2019). Exploring community stakeholders' perceptions of mass tourism: the case of Bruges. MPRA Paper No. 94223. Preuzeto s https://mpra.ub.uni-muenchen.de/94223/1/MPRA_paper_94223.pdf (7. 9. 2020.).

23. Higgins-Desbiolles, F., Carnicelli, S., Krolikowski, C., Wijesinghe, G., Boluk, K. (2019). Degrowing tourism: rethinking tourism. Journal of Sustainable Tourism, 27(12), 1926-1944. DOI: 10.1080/09669582.2019.1601732

24. Hospers, G.-J. (2019). Overtourism in European Cities: From challenges to Coping Strategies. CESifo Forum, ifo Institut - Leibniz-Institut für Wirtschaftsforschung an der Universität München, München, 20(3), 20-24.

25. Huete, R., Mantecón, A. (2018). The rise of tourismophobia. Research hypothesis or ideological noise? PASOS: Revista de Turismo y Patrimonio Cultural, 16(1), 9-19.

26. Hughes, N. (2018). 'Tourists go home': anti-tourism industry protest in Barcelona. Social Movement Studies, 17(4), 471-477. DOI: 10.1080/14742837.2018.1468244

27. Ioannides, D., Röslmaier, M., van der Zee, E. (2019). Airbnb as an instigator of 'tourism bubble' expansion in Utrecht's Lombok neighborhood. An International Journal of Tourism Space, Place and Environment, 21(5), 822-840. DOI: $10.1080 / 14616688.2018 .1454505$

28. Jamieson, W., Jamieson, M. (2019). Managing overtourism at the municipal/destination level. U R. Dodds i R. W. Butler (ur.) Overtourism: Issues, Realities and Solutions. Boston: De Gruyter. str. 219-233. DOI: 10.1515/9783110607369-015

29. Jover, J., Díaz-Parra, I. (2020). Who is the city for? Overtourism, lifestyle migration and social sustainability. Tourism Geographies. DOI: 10.1080/14616688.2020.1713878

30. Kádár, B. (2018.) Hotel development through centralized to liberalized planning procedures: Prague lost in transition. Tourism Geographies, 20(3), 461-480. DOI: 10.1080/14616688.2017.1375974

31. Ključnikov, A., Krajčík, V., Vincúrová, Z. (2018). International sharing economy: The case of Airbnb in the Czech Republic. Economics \& Sociology, 11(2), 126-137. DOI: 10.14254/2071789X.2018/11-2/9

32. Koens, K., Postma, A., Papp, B. (2018). Is Overtourism Overused? Understanding the Impact of Tourism in a City Context. Sustainability, 10(12), 4384. DOI: 10.3390/ su10124384

33. Krajinović, V. (2015). Propitivanje ključnih izazova u mjerenju održivog razvoja turizma. Acta Turistica, 27(1), 63-91.

34. Kuščer, K., Mihalič, T. (2019). Residents’ Attitudes towards Overtourism from the Perspective of Tourism Impacts and Cooperation - The Case of Ljubljana. Sustainability, 11(6), 1823. DOI: 10.3390/su11061823

35. Lucerne (2020). About Lucerne Tourism. Preuzeto s https://www.luzern.com/en/about-us/about-lucerne-tourism/ (7. 6. 2020.).

36. Martín Martín, J. M., Guaita Martínez, J. M., Salinas Fernández, J. A. (2018). An Analysis of the Factors behind the Citizen's Attitude of Rejection towards Tourism in a Context of Overtourism and Economic Dependence on This Activity. Sustainability, 10(8), 2851. DOI: $10.3390 /$ su10082851 
37. Martin-Fuentes, E., Nieto Ferrando, J., Marine-Roig, E., Ferrer-Rosell, B. (2020). From Blockbuster to Neighbourhood Buster: The Effect of Films on Barcelona. Sustainability, 12(6), 2290. DOI: 10.3390/su12062290

38. Milano, C., Novelli, M., Cheer, J. M. (2019a). Overtourism and degrowth: a social movements perspective. Journal of Sustainable Tourism, 27(12), 1857-1875. DOI: 10.1080/09669582.2019.1650054

39. Milano, C., Novelli, M., Cheer, J. M. (2019b). Overtourism and Tourismophobia: A Journey through Four Decades of Tourism Development, Planning and Local Concerns. Tourism Planning \& Development, 16(4), 353-357. DOI: 10.1080/21568316.2019.1599604

40. Milivojević, R. (2019). Prekomjerni turizam i njegovi učinci na razvoj turističkih destinacija. Diplomski rad. Ekonomski fakultet Zagreb. Dostupno na: https://zir.nsk.hr/ islandora/object/efzg\%3A3121

41. Moreno-Gil, S., Coca-Stefaniak, J. A. (2020). Overtourism and the sharing economy Tourism cities at a crossroads. International Journal of Tourism Cities, 6(1), 1-7. DOI: 10.1108/IJTC-03-2020-174

42. Muler Gonzalez, V., Coromina, L., Galí, N. (2018). Overtourism: residents' perceptions of tourism impact as an indicator of resident social carrying capacity - case study of a Spanish heritage town. Tourism Review, 73(3), 277-296. DOI: 10.1108/TR-08-20170138

43. Namberger, P., Jackisch, S., Schmude, J., Karl. M. (2019). Overcrowding, Overtourism and Local Level Disturbance: How Much Can Munich Handle?. Tourism Planning \& Development, 16(4), 452-472. DOI: 10.1080/21568316.2019.1595706

44. Nilsson, J. H. (2020). Conceptualizing and contextualizing overtourism: the dynamics of accelerating urban tourism. International Journal of Tourism Cities. DOI: 10.1108/ IJTC-08-2019-0117

45. Nolan, E., Séraphin, H. (2019). Venice: capacity and tourism. U R. Dodds i R. W. Butler (ur.) Overtourism: Issues, Realities and Solutions. Boston: De Gruyter. str. 139-151. DOI: 10.1515/9783110607369-010

46. NYCdata, (2019). International Visitors to New York City. Preuzeto s https://www. baruch.cuny.edu/nycdata/tourism/international_visitors.html (7. 6. 2020.).

47. O'Reilly, A. M. (1986). Tourism carrying capacity: Concept and issues. Tourism Management, 7(4), 254-258. DOI: 10.1016/0261-5177(86)90035-X

48. Oklevik, O., Gössling, S., Hall, C. M., Steen Jacobsen, J. K., Grøtte, I. P., McCabe, S. (2019). Overtourism, optimization, and destination performance indicators: a case study of activities in Fjord Norway. Journal of Sustainable Tourism, 27(12), 18041824. DOI: $10.1080 / 09669582.2018 .1533020$

49. Panayiotopoulos, A., Pisano, C. (2019). Overtourism Dystopias and Socialist Utopias: Towards an Urban Armature for Dubrovnik. Tourism Planning \& Development, 16(4), 393-410. DOI: 10.1080/21568316.2019.1569123

50. Papathanassis, A. (2017). Over-Tourism and Anti-Tourist Sentiment: An Exploratory Analysis and Discussion. "Ovidius" University Annals, Economic Sciences Series, $X V I I(2), 288-293$ 
51. Peeters, P., Gössling, S., Klijs, J., Milano, C., Novelli, M., Dijkmans, C., Eijgelaar, E., Hartman, S., Heslinga, J., Isaac, R., Mitas, O., Moretti, S., Nawijn, J., Papp, B., Postma, A. (2018). Research for TRAN Committee - Overtourism: impact and possible policy responses. Brussels: European Parliament, Policy Department for Structural and Cohesion Policies.

52. Perkumienè, D., Pranskūnienè, R. (2019). Overtourism: Between the Right to Travel and Residents' Rights. Sustainability, 11(7), 2138. DOI: 10.3390/su11072138

53. Pinke-Sziva, I., Smith, M., Olt, G., Berezvai, Z. (2019). Overtourism and the night-time economy: a case study of Budapest. International Journal of Tourism Cities, 5(1), 1-16. DOI: 10.1108/IJTC-04-2018-0028

54. Pirillo Ramos, S., Mundet, L. (2020). Tourism-phobia in Barcelona: dismantling discursive strategies and power games in the construction of a sustainable tourism city. Journal of Tourism and Cultural Change. DOI: 10.1080/14766825.2020.1752224

55. Prague City Tourism (2020). Guests and nights - Prague - 2012-2020. Preuzeto s https://www.praguecitytourism.cz/en/our-services/statistics/guests-and-nights-reviseddata-2012-2019-14836 (7. 6. 2020.).

56. Responsible Travel, n.d. What is overtourism. Preuzeto s https://www.responsibletravel.com/copy/what-is-overtourism (5. 6. 2020.).

57. Rončák, M. (2019). Prague and the impact of low-cost airlines. U R. Dodds i R. W. Butler (ur.) Overtourism: Issues, Realities and Solutions. Boston: De Gruyter. str. 152168. DOI: $10.1515 / 9783110607369-011$

58. Seraphin, H., Sheeran, P., Pilato, M. (2018). Over-tourism and the fall of Venice as a destination. Journal of Destination Marketing \& Management, 9, 374-376. DOI: 10.1016/j.jdmm.2018.01.011

59. Smith, M. K., Pinke Sziva, I., Olt, G. (2019). Overtourism and Resident Resistance in Budapest. Tourism Planning \& Development, 16(4), 376-392. DOI: $10.1080 / 21568316.2019 .1595705$

60. Taş Gürsoy, I. (2019). Beauty and the Beast: A Fairy Tale of Tourismophobia. Tourism Planning \& Development, 16(4), 434-451. DOI: 10.1080/21568316.2019.1582086

61. Thurnell-Read, T. (2012). Tourism place and space: British stag Tourism in Poland. Annals of Tourism Research, 39(2), 801-819. DOI: 10.1016/j.annals.2011.09.009

62. UNWTO (2018). Overtourism? Understanding and Managing Urban Tourism Growth beyond Perceptions. Madrid: World Tourism Organization.

63. UNWTO (2019a). International Tourism Highlights 2019 Edition. Madrid: World Tourism Organization. DOI: 10.18111/9789284451152

64. UNWTO (2019b). Overtourism? Understanding and Managing Urban Tourism Growth beyond Perceptions. Volume 2: Case Studies. Madrid: World Tourism Organization.

65. UNWTOa, n.d. Sustainable tourism. Preuzeto s https://sustainabledevelopment.un.org/topics/sustainabletourism (5. 6. 2020.).

66. UNWTOb, n.d. Tourism Statistics. Preuzeto s https://www.e-unwto.org/toc/unwtotfb/ current (5. 6. 2020.). 
67. Wai Lai, I. K., Hitchcock, M. (2017). Local reactions to mass tourism and community tourism development in Macau. Journal of Sustainable Tourism, 25(4), 451-470. DOI: 10.1080/09669582.2016.1221413

68. Wall, G. (1996). Rethinking Impacts of Tourism. Progress in Tourism and Hospitality Research, 2(3-4), 207-215. DOI: 10.1002/pth.6070020302

69. Wall, G. (1997). Sustainable tourism - unsustainable development. U S. Wahab i J. J. Pigram (ur.), Tourism, Development and Growth. New York: Routledge. str. 33-49.

70. Wall, G. (2019). Perspectives on the environment and overtourism. U R. Dodds i R. W. Butler (ur.) Overtourism: Issues, Realities and Solutions. Boston: De Gruyter. str. 2745. DOI: $10.1515 / 9783110607369-003$

71. Wall, G. (2020). From carrying capacity to overtourism: a perspective article. Tourism Review, 75(1), 212-215. DOI: 10.1108/TR-08-2019-0356

72. Weber, F., Eggli, F., Ohnmacht, T., Stettler, J. (2019). Lucerne and the impact of Asian group tours. U R. Dodds i R. W. Butler (ur.) Overtourism: Issues, Realities and Solutions. Boston: De Gruyter. str. 169-184. DOI: 10.1515/9783110607369-012

73. World Population Review, n.d. World City Population. Preuzeto s https://worldpopulationreview.com/world-cities/ (7. 6. 2020). 